\title{
The Knowledge Of Early Childhood Education Teachers About Natural Disaster Management
}

\author{
Yeni Solfiah, Devi Risma, Hukmi, Rita Kurnia \\ Teachers' Training and Education Faculty of Early Childhood Education at Riau University \\ yenisolfiah11@gmail.com
}

\begin{abstract}
Indonesia is a country that is prone to natural disasters. Natural disasters enable occur spontanously everytime. Therefore, disaster education is needed through disaster management learning as soon as possible. Early Childhood Education Teachers have an important role to provide disaster management knowledge to children, so that children have awareness of disasters. This study aims to determine the level of disaster management knowledge of Early Childhood Education teachers in Pekanbaru. The research method used is quantitative descriptive by using a scale for measuring disaster management, including indicators of mitigation, preparedness, response and recovery. The population of this study was PAUD teachers in Pekanbaru and it is totally 73 people. The results of the study indicates the level disaster management knowledge of Early Childhood Education teachers in Pekanbaru is in the low category seen from the indicator score obtained which is 35\% of the expected. Based on four indicators of disaster management knowledge, it is known that teacher' knowledge is higher in mitigation indicators which is $56.16 \%$ and preparedness which is $30.26 \%$.
\end{abstract}

Keywords: Knowledge, Natural Disaster Management, Early Childhood Education Teachers

\begin{abstract}
ABSTRAK
Indonesia adalah negara rawan bencana alam. Bencana alam memungkinkan terjadi secara spontan. Oleh karena itu, pendidikan bencana diperlukan melalui pembelajaran manajemen bencana. Pendidikan Anak Usia Dini bagi guru memiliki peran penting untuk memberikan pengetahuan manajemen bencana kepada anak-anak, sehingga anak-anak memiliki kesadaran akan bencana. Penelitian ini bertujuan untuk mengetahui tingkat pengetahuan manajemen bencana guru Pendidikan Anak Usia Dini di Pekanbaru. Metode penelitian yang digunakan adalah deskriptif kuantitatif dengan menggunakan skala untuk mengukur manajemen bencana, termasuk indikator mitigasi, kesiapsiagaan, respon dan pemulihan. Populasi penelitian ini adalah guru PAUD di Pekanbaru, totalnya 73 orang. Hasil penelitian menunjukkan tingkat pengetahuan manajemen bencana bagi guru PIAUD di Pekanbaru berada
\end{abstract}


dalam kategori rendah dilihat dari skor indikator 35\% dari yang diharapkan. Berdasarkan empat indikator pengetahuan manajemen bencana, diketahui bahwa pengetahuan guru lebih tinggi dalam indikator mitigasi yaitu 56,16\% dan kesiapsiagaan adalah 30,26\%.

\section{Keywords: Knowledge, Natural Disaster Management, Early Childhood Education Teachers}

\section{INTRODUCTION}

Indonesia is located on three tectonic plates, namely Australia, Eurasia and the Pacific. It is not surprising, if natural disasters are often comes to this country and that is known "Emerald Equator". There are floods, landslides, tornado, volcanic eruptions, earthquakes, tsunamis, droughts and deforestation which occur throughout the Indonesian archipelago. Based on the high level of disaster vulnerability in Indonesia, it is very important that disaster management education is carried out. According to Winarni and Purwandari (2018), education is one of the strategic and effective efforts to provide disaster management knowledge and make people aware of disasters. In other words, the educational process that occurs in various educations is the best ways to reduce losses caused by natural disasters.

Disasters are harmful. Eventhough, to reduce this losses so that people needs to prepare themselves. One of the effort is implementing disaster management. Disaster management is subject that explains the disasters and all aspects related to the risk, and how to solve it. According to P. Nugrahajati (2012) disaster management is a strategy and policy in anticipating, preventing and managing disasters. It summed up that knowledge of disaster management can minimize and reduce the risk of the disasters.

The implementations of disaster management in Law No. 24 of 2007 chapter 1 paragraph 5 is a series of efforts include the establishment of renewal policies that is being risk of disaster, disaster prevention activities, emergency response, and rehabilitation. On the other hand, reduceing losses from a disaster event, it can be implemented in several stages and involves the society. It is similar to the teacher who interacts with children in the school environment every day.

The guidelines in the Hyogo Framework (2005), he determined there are five priorities in order to minimize impacts and losses in a natural disaster. The five specializations covering disaster risk education are national and local priorities, increasing early warning, using innovation, technology, culture, education and resilience, reducing risk and strengthening preparedness in dealing with disasters at all levels. Based on these guidelines, it can be illustrated that education is a component that can help reduce risks and losses when natural 
disasters occur. Therefore schools and teachers need to prepare themselves in providing their students with knowledge and experience to face natural disasters. However, the knowledge is being useful information to the children.

Meanwhile, Carter (2008) recommends that each country choose the form of disaster management cycle that is appropriate to their needs. Based on this, the researcher took four stages of disaster management from Carter (2008) in accordance with the research needs:

a. Mitigation, actions taken (usually in the form of specific programs) to reduce the impact of disasters on a nation or community. For example, developing and implementing building codes can reduce damage and losses if earthquakes and storms occur. This method may prevent some catastrophic effects; other effects will be reduced if there is an inappropriate action.

b. Preparedness, actions that allow governments, communities and individuals to respond quickly and effectively to the disaster situations. There are the preparation stages include formulating an appropriate disaster management plan, maintaining the resources, and giving a training to the society.

c. Response, actions that are usually taken immediately before and after the impact of a disaster. They are directed to save lives, protect their properties, and focus on the damage and other effects caused by disasters.

d. Recovery, the process that peoples and countries are helped to return the levels of them after a disaster. The recovery process can be very protracted, up to 5-10 years or more. It is usually done by including other aspects such as restoration and reconstruction.

Based on the description above, it can be described that disaster management consists of several stages. However, the presence of teachers at schools occupies a strategic position, both to enrich the knowledge, instill children's attitudes in caring for natural disasters. In the teaching and learning process, an early childhood education teacher conveys a variety of information and knowledge that will be the foundation for children in further education. It is similar to A. Rusilowati, Supriyadi, A. Binadja and S.E.S. Mulyani (2012) that teachers occupy a significant position in preparing their students to understand and how to act when natural disasters occur. It can be concluded that the teacher has the function to transfer information and knowledge how to recognize and readiness to face of natural disasters.

Early childhood education teacher have an important role in providing knowledge about disaster management to their students. It aims to reduce losses from natural disasters such as loss of lives, damage a lot of things and trauma. And the knowledge possessed by the Kindergarten, Vol. 2, No. 1, April 2019, Hal. 159-166 
teacher will have an impact on the information obtained by children through the learning process. It is similar to Muhammad Rizal Pahleviannur (2019) the risk reduction of natural disasters can be implemented into the education sector and its purpose to build a resilient generation. In other words teachers are expected to have sufficient knowledge in introducing information related to natural disaster management. So with this knowledge, the learning process that takes place in early childhood education classes can produce agile children facing various natural disaster events.

The teachers' knowledge of disaster management should cover a variety of important aspects surrounding disaster management. For example, the introduction of disasters, the potential of disasters in the environment, disasters that often appeared in the environment, recognize and increase awareness of the signs of disaster, understand the forms of anticipation, the impact of natural disasters, how to deal with disaster conditions and how to save themselves from disaster. Aldila Rahma (2018) states that schools are an effective institutions in supplying the knowledge, skills and attitudes of students who are going to be agents of change in their society. Based on this condition, teachers and schools are expected to be able to create communities that have the awareness to prepare themselves in facing the natural disasters.

Knowledge is the process of utilizing the five senses and mind that will give information. There are ways of increasing knowledge involve sight, hearing, touch, taste and the process of using the mind. In carrying out their duties, an early childhood education teacher is required to have sufficient knowledge to support his competence as an educator. Early childhood education teacher's knowledge is required in the teaching and learning process, because it will be a role model for children. Therefore, early childhood education teachers have a big role in providing knowledge about disaster management to their students. Torani, et.all (2019) said that individuals who have knowledge of dealing with natural disasters through training will be ready and they will reduce greater losses in the future. In conclusion, early childhood education teachers are able to make a major contribution in preparing children to be skilled in saving themselves when natural disasters come suddenly.

\section{METHOD}

This research was conducted in Pekanbaru, Riau Province. The populations in this study were early childhood education teachers in Tampan District, Pekanbaru and took samples 73 people from 201 people. And, the objectives of the research with quantitative descriptive 
survey methods through the scale measurement of disaster management knowledge that is distributed.

\section{RESULT AND DISCUSSION}

a. The Level of disaster management knowledge of Early Childhood Education Teachers

Based on descriptive data results of the study determined the category of disaster management knowledge of Early Childhood Education teacher in Pekanbaru from mapping in the following table:

TABLE 1.

THE CATEGORIZATION SCORE OF DISASTER MANAGEMENT KNOWLEDGE

\begin{tabular}{lccc}
\hline \multicolumn{1}{c}{ Category } & Score & F & $\mathbf{\%}$ \\
\hline High & $\mathrm{X} \geq 25.33$ & 0 & $0.00 \%$ \\
Medium & $13,33 \leq \mathrm{X}<25.33$ & 35 & $47.95 \%$ \\
Low & $\mathrm{X}<13,33$ & 38 & $52.05 \%$ \\
\hline \multicolumn{2}{c}{ Total } & $\mathbf{7 3}$ & $\mathbf{1 0 0 . 0 0 \%}$ \\
\hline
\end{tabular}

A clearer picture of Early Childhood Education teachers' knowledge of disaster management in Pekanbaru can be seen in the graph below:

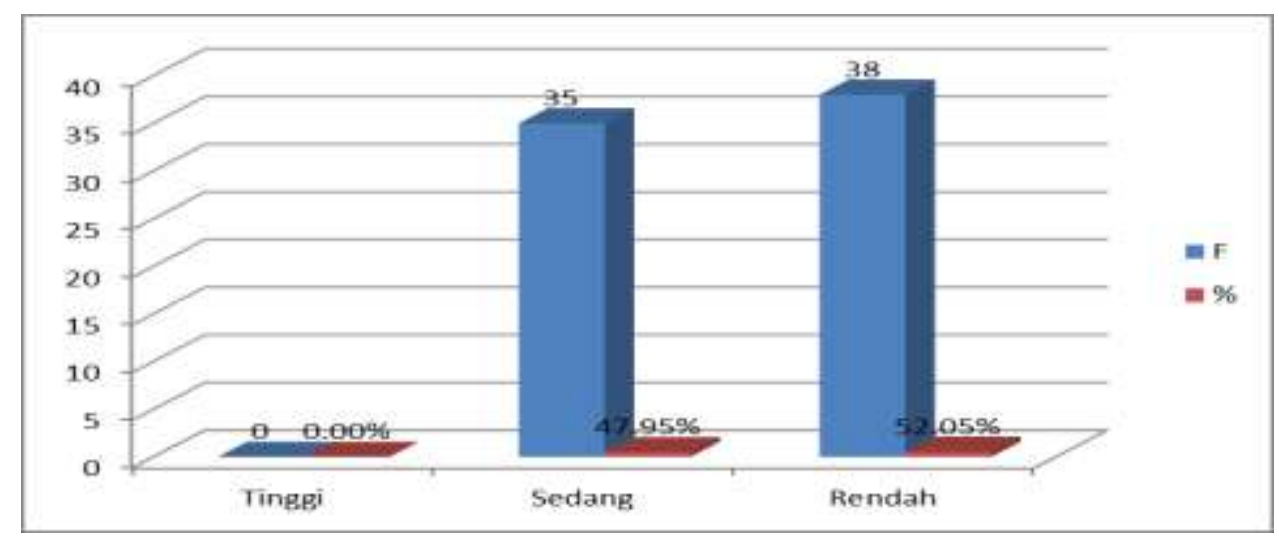

Graph 1. The Distribution Category of Early Childhood Education Teachers' Knowledge about Disaster Management 
From Table 1 and graph 1 above shows that the tendency of Early Childhood Education teachers' knowledge about disaster management in Pekanbaru is in the high category $(0 \%)$, while the remaining $47.95 \%$ is in the medium category and $52.05 \%$ in the low category. It illustrates that Early Childhood Education teachers' knowledge about disaster management is low.

b. The Percentage Score of Early Childhood Education Teachers' Knowledge Indicators about Disaster Management

The percentage of early childhood education teachers' knowledge about disaster management in Pekanbaru can be mapped into indicators below:

TABLE 2.

THE PERCENTAGE SCORE OF EARLY CHILDHOOD EDUCATION TEACHERS' KNOWLEDGE INDICATORS ABOUT DISASTER MANAGEMENT

\begin{tabular}{clcccccc}
\hline No & Indicator & $\begin{array}{c}\text { Total } \\
\text { Items }\end{array}$ & $\begin{array}{c}\text { Ideal } \\
\text { Score }\end{array}$ & $\begin{array}{c}\text { Factual } \\
\text { Score }\end{array}$ & Average & $\mathbf{\%}$ & Category \\
\hline 1 & Mitigation & 10 & 730 & 410 & 5.62 & $56.16 \%$ & Medium \\
2 & Preparedness & 11 & 803 & 243 & 3.33 & $30.26 \%$ & Low \\
3 & Response & 9 & 657 & 172 & 2.36 & $26.18 \%$ & Low \\
4 & Recovery & 8 & 584 & 146 & 2.00 & $25.00 \%$ & Low \\
\hline & Total & $\mathbf{3 8}$ & $\mathbf{2 7 7 4}$ & $\mathbf{9 7 1}$ & $\mathbf{1 3 . 3 0}$ & $\mathbf{3 5 . 0 0 \%}$ & Low \\
\hline
\end{tabular}

Based on table 2 , it is known that the percentage of early childhood education teachers' knowledge level about disaster management in Pekanbaru for each indicator is higher in mitigation that is achieved $56.16 \%$ and recovery is lower than another indicator is obtained $25 \%$.

c. Discussion of Early Childhood Education Teachers' Knowledge Level about Disaster Management

The results of research on the level of early childhood education teachers' knowledge level about disaster management, there is not people have high disaster management knowledge but 35 people have disaster management knowledge in the medium category and 38 people are in the low category (Table 1). 
As a result, early childhood education teachers' knowledge level about disaster management in Pekanbaru City is in the low category (35\%). It is obtained from the comparison of factual scores with ideal scores of one hundred percent, which is 971 / $2774 \times 100 \%=35 \%$. The data shows that the level of early childhood education teachers' about disaster management is low in Pekanbaru. Teachers are lack of management knowledge in terms of disaster mitigation, disaster awareness, disaster response and disaster recovery. And it can be taken from the percentage score of disaster management knowledge indicator. In the mitigation indicator, the results of a score of $56.16 \%$ indicate early childhood education teachers in Pekanbaru are categorized sufficient to know and quite understand the actions that must be done to reduce the impact of disasters. In the preparedness indicator, the results of a score of $30.26 \%$ determine that early childhood education teachers are lack knowledge of the fast and effective actions that must be done for disaster management. For example, they always prepare a bag containing a pair of clothes, important documents, food, drink, a flashlight and medicines for areas that are often disastrous.

On the response indicator, the results of the study score were $26.18 \%$. It described that early childhood education teacher in Pekanbaru do not know what to do immediately, both before and after a disaster occurs. For example, if floods come, they run to the plateau specified in the disaster management plan. And for recovery indicators, it is obtained $25 \%$ and it indicates early childhood education teacher are lack of knowledge in Pekanbaru about handling a disaster after it occurs in daily life.

\section{CONCLUSION}

The knowledge of disaster management of early childhood education teachers in Pekanbaru is categorized into low level $(35 \%)$, it means that most early childhood education teachers in Pekanbaru are lack of knowledge in disaster management. Early childhood education teachers in Pekanbaru is lack of knowledge to minimize and or reduce the impact of disasters. It is expected that early childhood education teacher in Pekanbaru are able to improve their knowledge of disaster management and apply it learning process continuosly. As the result, the children have the knowledge and skills in handling future disasters and it can reduce the impact of disasters that occur in the future. 


\section{ACKNOWLEDGEMENT}

Thank you to LPPM Riau University (Institute for Research and Encoding) and Kindergarten of 'Teacher' training and Education Faculty of Riau University for support to the researchers to carry out this research.

\section{REFERENSI}

A. Rusilowati, Supriyadi, A. Binadja dan S.E.S. Mulyani. (2012). Mitigasi Bencana Alam Berbasis Pembelajaran Bervisi Science Environment Technology and Society. Jurnal Pendidikan Fisika Indonesia. Volume 8. Hal. 51-60.

Aldila Rahma. (2018). Implementasi Program Pengurangan Risiko Bencana (PRB) Melalui Pendidikan Formal. Jurnal Varia Pendidikan. Volume 30 No.1. Hal.1-11

Carter, W. Nick. (2008). Disaster Management : A Disaster Manager's Handbook. Manila : Asian Development Bank.

Hyogo Framework. (2005). Hyogo Framework for Action 2005-2015. http://psikologikebencanaan.wg.ugm.ac.id/index.php/advokasi/28-hyogoframework-for-action-2005-2015. Accessed on September $7^{\text {th }} 2019$

Muhammad Rizal Pahleviannur. (2019). Edukasi Sadar Bencana Melalui Sosialisasi Kebencanaan Sebagai Upaya Peningkatan Pengetahuan Siswa Terbadap Mitigasi Bencana. Jurnal Pendidikan dan Ilmu Sosial. Volume 29 No.1. Hal.49-55

P. Nugrahajati. (2012). Bencana Alam Pencegahan dan Penanggulangannya. Jakarta : Wahyu Agria. Sogand Torani, Parisa Moradi Majd, Shahnam Sedigh Maroufi, Mohsen Dowlati, and Rahim Ali Sheikhi. (2019). The importance of education on disasters and emergencies: A review article. Journal of Education and Health Promotion. Volume 8.

https://www.ncbi.nlm.nih.gov/pmc/articles/PMC6512217/\#ref15. Accessed on September $6^{\text {th }} 2019$

Undang-undang Republik Indonesia No. 24 Tahun 2007 tentang Penanggulanan Bencana.

Winarni, Endang Widi \& Purwandari, Endina Putri. (2018). Disaster Risk Reduction for Earthquake Using Mobile Learning Application to Improve the Students Understanding in Elementary School. Mediteranian Journal of Social Sciences, 9 (2), 205-214. https://content.sciendo.com/downloadpdf/.../article-p205.xm. Accessed on September $6^{\text {th }} 2019$ 